\title{
Analytical Study for the Development of Interaction Diagram of the Fire-damaged RC Columns with Varied Heated Areas
}

\author{
Ryu, Eunmi*, Kim, Heesun**, and Shin, Yeongsoo**
}

\begin{abstract}
Inconsistent damages over the surface of structural members are expected from a compartment fire situation, which may cause additional reduction of structural performances especially in the case of reinforced concrete (RC) columns. In this study, an analytical modeling method for simplified cross section was proposed and validated for the prediction of axial strength of fire-damaged RC columns. The proposed modeling method was subsequently used to develop interaction diagrams of fire-damaged RC columns with varied heat exposure areas. Compared to the experimental results, it was found that the P-M interaction diagram allowed estimating axial force and moment capacities of the fire-damaged concrete columns.
\end{abstract}

Key words : RC Column, Fire, Heated Area, Finite Element Analysis, Interaction Diagram

\section{요 지}

특정한 구역에서 화재가 발생하는 경우 구조부재는 일부 표면만 화재에 노출될 가능성이 있으며, 이는 철근 콘크리트 기둥에서 구조성능을 추가적으로 저감시키는 요인이 된다. 따라서 이 연구에서는 화재 피해를 입은 철근 콘크리트 기둥의 축력을 예측하기 위해 단면을 단순화 시키는 기법으로 모델링 방법을 제안하고 검증하였다. 제안된 모델링 기법은 P-M 상관도를 구현하는 데에 사용되었으며, 실험결과와의 비교검증을 통해 제안된 P-M 상관도가 다양한 면적이 화재에 노출된 철근 콘크리트 기둥의 축력과 모멘트 성능을 예측하는 데에 활용 가능한 것으로 파악하였다.

핵심용어 : RC 기둥, 화재, 가열면, 유한요소해석, P-M 상관도

\section{Introduction}

Fire resistance of Reinforced Concrete (RC) columns is important to ensure the overall safety of structures when a fire occurs. When RC columns are exposed to fire, their capacities are significantly reduced. In addition, the surface of column can partially be exposed to fire depending on fire condition and floor plan, which cause asymmetric behaviors of fire-damaged columns.
There have been many experimental and numerical studies on the behavior of columns under fire conditions. The paper by Tan and Yao (2003) developed a simple and rational method to predict the fire resistance of RC columns subjected to four-face heating. Both uniaxial and biaxial bending of columns was considered. In the paper by Mao and Kodur (2011), an experimental study were constructed to study Concrete Encased Steel (CES) columns under standard fire exposure conditions were presented. The test parameters

*정회원, 이화여자대학교 건축도시시스템공학과 박사(E-mail: ryue@ewha.ac.kr)

Member, Ph.D., Department of Architectural and Urban Systems Engineering, Ewha Womans University

**정회원, 이화여자대학교 건축도시시스템공학과 교수

Member, Professor, Department of Architectural and Urban Systems Engineering, Ewha Womans University

***교신저자. 정회원, 이화여자대학교 건축도시시스템공학 교수(Tel: +82-2-3277-2596, Fax: +82-2-3277-6875, E-mail: shinys@ewha.ac.kr)

Corresponding Author, Member, Professor, Department of Architectural and Urban Systems Engineering, Ewha Womans University 
include column size, 3- and 4-side fire exposure, load intensity and load eccentricity. Buch and Sharma (2019) tested to determine the influence of relative levels of spalling under eccentric loads on fire resistance of RC columns. Interaction diagram is useful index for design and evaluating the capacity of fire-damaged columns. Caldas et al. (2010) presented a procedure to obtain interaction diagrams of RC sections of general shape subjected to fire action. Kim (2008) studied spalling, temperature distribution of interior column, residual strength and movement of column in eccentric loading with expose time of high temperature. And P-M interaction diagram was made according to various column section using nonlinear analyses. El-Fitiany and Youssef (2014) constructed interaction diagrams for heated RC columns using practical approach. In addition, this paper presents the derivation of a set of formulas that can be used to estimate the average temperature distribution within the concrete section and the corresponding internal forces. Law and Gillie (2010) reported a new method of creating two- or three-dimensional interaction diagrams under any temperature field based on the tangent stiffness matrix of a section. Among many related researches, effect of heated areas on the structural behaviors of fire-damaged columns for the consideration of real fire situation has been studied limitedly. Moreover, P-M interaction diagram of the fire-damaged concrete columns with various heat exposure areas has not been developed.

Therefore, this study aimed to develop modeling method and provide interaction diagrams of fire-damaged RC columns with consideration of various heat exposure areas. Toward the goal, Finite Element (FE) analyses with a simplified section method were performed and the analytical results were compared with experimental results for validation. Then, $\mathrm{P}-\mathrm{M}$ interaction diagrams of fire-damaged RC columns with various heat exposure areas were established using the proposed modeling method.

\section{Analytical Approach and Validation}

\subsection{Analytical Approach}

Test specimens were heated for two hours and then were cooled for one week. Axial loading tests were performed to measure the residual strength of the fire-damaged columns with same condition as analyses. The details of experimental methods can be found from the paper (Ryu, 2020). A total of five models having different heat exposure areas of none to four side surfaces were modeled using ABAQUS 6.3-10 (Dassault Systèms, 2013) as listed in Table 1. The FE models were generated with eight-node solid elements, having width, depth and height equal to 350,350 , and $1,500 \mathrm{~mm}$, respectively. These dimensions were determined to be same as test specimens for the validation with experiments (Ryu, 2020). Elements for the reinforcing steel bars were included in the model by assigning steel material properties to the meshes where the steel bars were located, as illustrated in Fig. 1. Rest of the elements were modeled with concrete material properties.

Table 1. List of Models

\begin{tabular}{c|c|c}
\hline No. & Model Name & Heated Surface \\
\hline 1 & C0 & None \\
\hline 2 & H1 & One side surface \\
\hline 3 & H2 & Two side surfaces \\
\hline 4 & H3 & Three side surfaces \\
\hline 5 & H4 & Four side surfaces \\
\hline
\end{tabular}

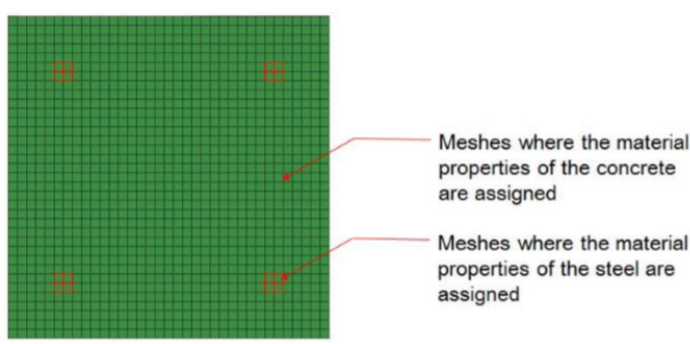

(a) Cross Sectional View

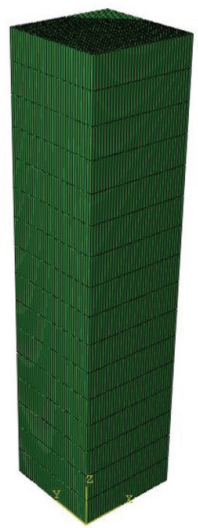

(b) $3 \mathrm{D}$ View

Fig. 1. FE Model of the RC Columns

For the thermal analyses, elevated temperatures were applied to the designated surfaces according to ISO 834 (1999) standard time-temperature curve, while initial temperature was given as room temperature to all nodes on the surfaces. During the analyses, time increment was controlled automatically with ranges from 0.001 to $100 \mathrm{sec}$. 
The temperature dependent thermal and mechanical properties such as effective specific heats, conductivities, the elastic modulus, the compressive and tensile strengths for the concrete and steel referred to Eurocode 2 (EN 1992-1-2, 2004) and included in the models. The values of those for the concrete and steel with the increasing temperature are illustrated in Fig. 2.

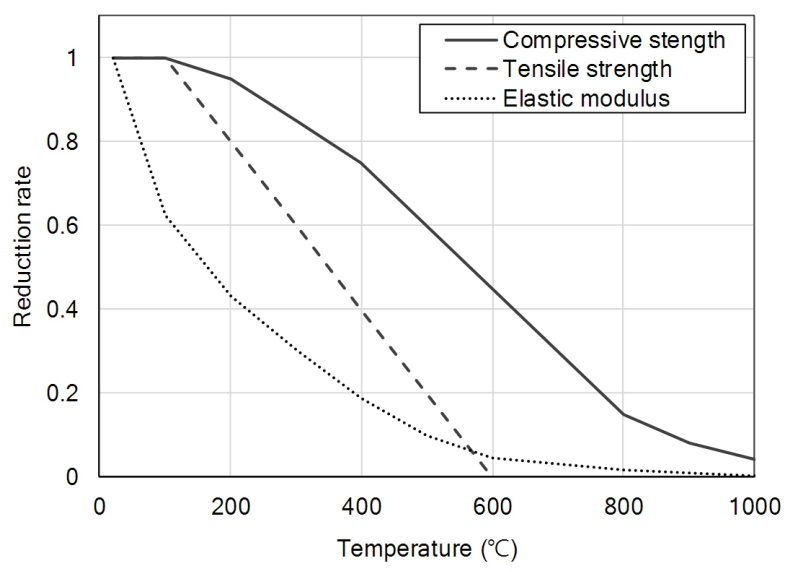

Fig. 2. Reduction Rates of Material properties for Concrete with Temperatures

From the thermal analyses, temperature distributions inside the column were obtained, which could determine mechanical material properties of fire-damaged concrete and steel for the structural analyses.

For the structural analyses of the fire-damaged columns, two different modeling methods were used; original section method and simplified section method as shown in Fig. 3. Original section method was to assign temperature dependent mechanical material properties of concrete and steels according to the temperature distributions obtained from the thermal analyses. Therefore, relatively low stress-strain curve of the concrete was assigned to the elements near heated surface while the stress-strain curve of the concrete at room temperature was assigned to the elements near unheated area. In the simplified section method, the part exposed to temperatures above $500{ }^{\circ} \mathrm{C}$ or $700{ }^{\circ} \mathrm{C}$ was considered extremely damaged and excluded from the model. Then, the remained part was modeled with material properties at room temperature. In this manner, the less number of elements was required compared to the case of original section method, and material properties only at room temperature was needed. For the validation, the results predicted from the simplified section method were compared with the experimental results. In addition, within the simplified section method, the analytical results based on $700{ }^{\circ} \mathrm{C}$ isotherm and $500{ }^{\circ} \mathrm{C}$ isotherm were compared each other to determine temperature criteria. The $500{ }^{\circ} \mathrm{C}$ isotherm method is referred to Eurocode 2 and generally used to estimate the fire resistance of $\mathrm{RC}$ element. For both original section method and simplified section method, concrete damaged plasticity constitutive model was used.

Loading and boundary conditions were prescribed such that the top surface was axially loaded and nodes on the bottom surfaces were fixed.

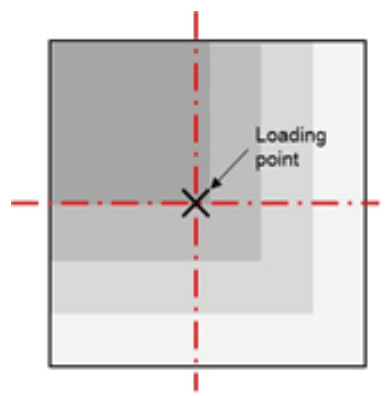

(a) Original Section Method

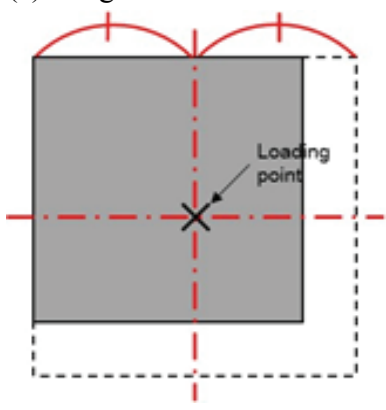

(b) Simplified Section Method

Fig. 3. Description of Original Section Method and Simplified Section Method

\subsection{Validation}

\subsubsection{Heat Transfer Analysis}

Fig. 4. shows the representative time-temperature curves of specimen $\mathrm{H} 2$ obtained experimentally and analytically. Table 2. shows maximum temperatures of RC columns obtain from experiments and analyses (Ryu, 2020). From the figure, it was found that the temperature distributions of the model predicted by the heat transfer analyses were in good agreement with experimental results. The differences between the experimental and analytical results of temperature distributions were within $50{ }^{\circ} \mathrm{C}$ for all the models from $\mathrm{H} 1$ to $\mathrm{H} 4$. Therefore, the temperature distributions obtained from the thermal analyses may be used to model fire-damaged RC columns for structural analyses. 


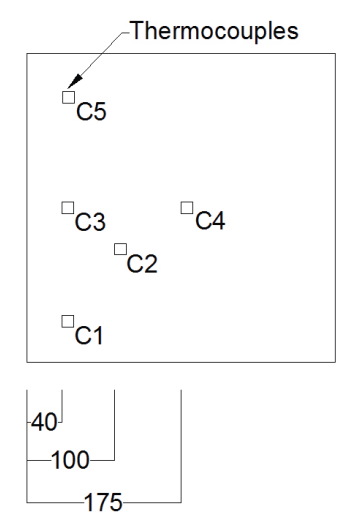

(a) Location of Thermocouples inside the Column

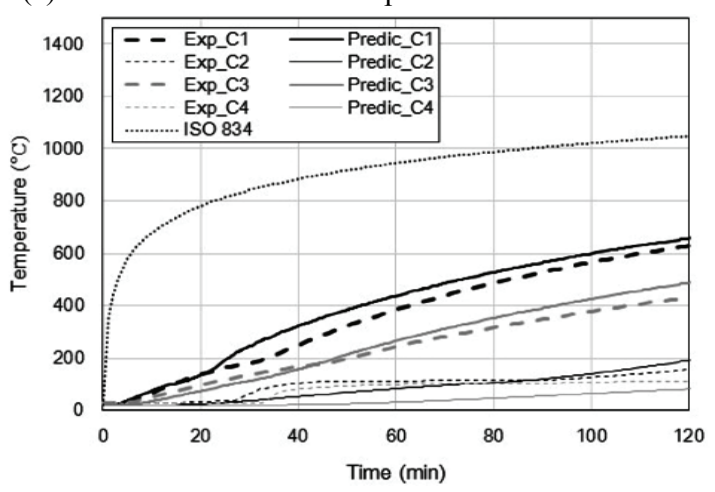

(b) Time-temperature Curves of $\mathrm{H} 2$ obtained Experimentally and Analytically

Fig. 4. Validation of Thermal Analysis

Table 2. Maximum Temperature of Columns

\begin{tabular}{c|c|c}
\hline Specimen & $\begin{array}{c}\text { Maximum temperature } \\
\text { from experiment }\left({ }^{\circ} \mathrm{C}\right)\end{array}$ & $\begin{array}{c}\text { Maximum temperature } \\
\text { from analysis }\left({ }^{\circ} \mathrm{C}\right)\end{array}$ \\
\hline $\mathrm{H} 1$ & 436 & 490 \\
\hline $\mathrm{H} 2$ & 630 & 658 \\
\hline $\mathrm{H} 3$ & 598 & 658 \\
\hline $\mathrm{H} 4$ & 494 & 660 \\
\hline
\end{tabular}

\subsubsection{Structural Analysis}

In order to validate the simplified section method, the analytical results of maximum loads were compared with experimental results as shown in Fig. 5. In addition, to determine temperature criteria for the simplified section method, predicted results based on $700{ }^{\circ} \mathrm{C}$ isotherm (the proposed isotherm) and $500{ }^{\circ} \mathrm{C}$ isotherm (following Eurocode 2) were compared each others. The differences of maximum loads between the experimental and analytical results were significantly large as $10 \sim 16 \%$ when the analytical method used $500{ }^{\circ} \mathrm{C}$ isotherm. On the other hand, the maximum loads obtained analytically based on $700{ }^{\circ} \mathrm{C}$ isotherm were similar to those of specimens obtained from experiments. The differences of maximum loads of columns between the experimental results and analytical results based on $700{ }^{\circ} \mathrm{C}$ isotherm were within $5 \%$. It can be found that the $500{ }^{\circ} \mathrm{C}$ isotherm method suggested to Eurocode 2 is conservative to estimate the structural behavior of fire-damaged column because analytical results obtained from $500{ }^{\circ} \mathrm{C}$ isotherm method were considerably lower than experimental results. However, in this study, the results obtained from simplified section method with 700 isotherm were found to be closer to the experimental results, compared to those obtained from simplified section method with 500 isotherm.

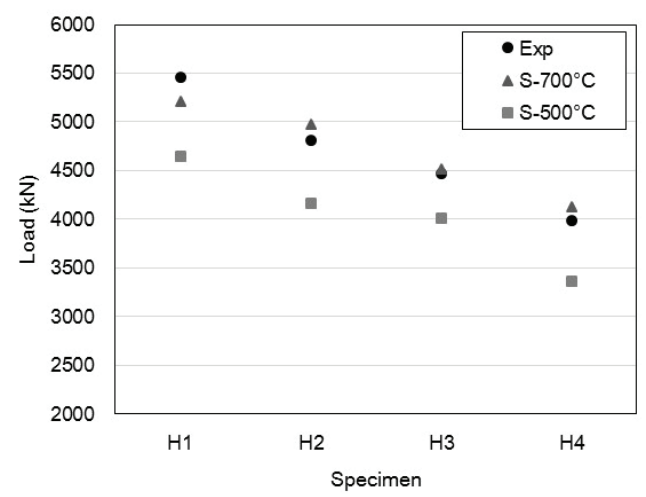

Fig. 5. Maximum Loads of the Fire-damaged Columns Obtained from Experiments and Analyses

\section{P-M Interaction Diagram of Fire-damaged Column}

To estimate the load capacity of fire-damaged column, the P-M interaction diagrams obtained using Eqs. (1) and (2) were plotted as solid and dashed lines of Figs. 6(a) (d). These diagrams considered simplified section based on 500 ${ }^{\circ} \mathrm{C}$ and $700{ }^{\circ} \mathrm{C}$ isotherm. Once values were obtained at several points, the P-M interaction diagram of the fire-damaged column was plotted by linking between the points. In addition, results obtained from the $\mathrm{FE}$ analysis using the original section method were plotted together with the P-M interaction diagrams for validation.

$$
\begin{aligned}
& P_{n}=0.85 f_{c k} a b+A_{s}^{\prime} f_{s}^{\prime}-A_{s} f_{s} \\
& M_{n}=P_{n} e
\end{aligned}
$$

where, $f_{c}=$ Compressive strength of concrete (MPa)

$a=$ Depth of equivalent rectangular stress block (mm) $b=$ Width of column (mm)

$A_{s}=$ Area of compression reinforcement $\left(\mathrm{mm}^{2}\right)$ 
$A^{\prime}{ }_{s}=$ Area of tension reinforcement $\left(\mathrm{mm}^{2}\right)$

$f_{s}=$ Stress in tension steel $(\mathrm{MPa})$

$f^{\prime}{ }_{s}=$ Stress in compression steel $(\mathrm{MPa})$

Figs. 6(a) (d) show P-M interaction diagrams of the fire-damaged columns in addition with the analytical results obtained using the original section method. The difference of P-M interaction diagrams of the columns obtained from the simplified section method based on $700{ }^{\circ} \mathrm{C}$ isotherm and $500{ }^{\circ} \mathrm{C}$ isotherm were $3 \sim 13 \%$. When compared with the analytical results obtained using the original section methods, the P-M interaction diagrams from the simplified section method based on $700{ }^{\circ} \mathrm{C}$ isotherm matched better than the case of $500{ }^{\circ} \mathrm{C}$ isotherm. Therefore, the P-M interaction diagram using the simplified section method based on 700 ${ }^{\circ} \mathrm{C}$ isotherm can be used to predict the strength and moment at various heated area.

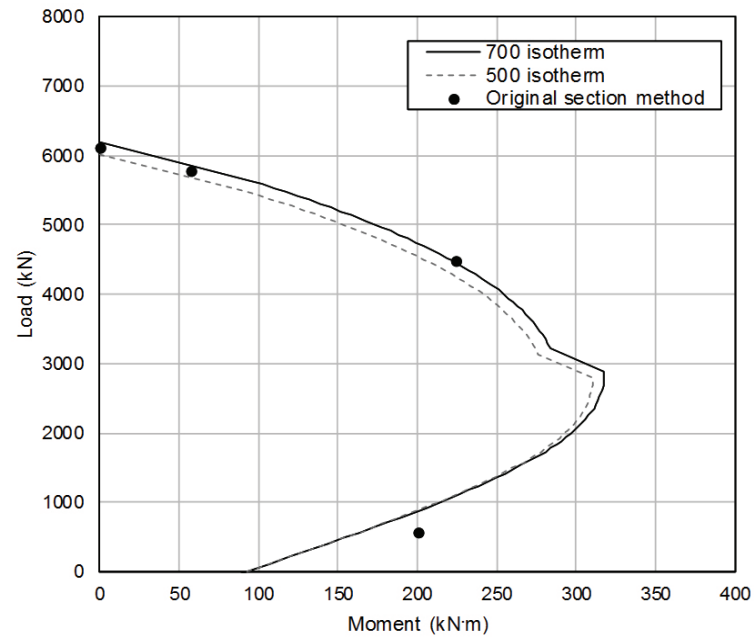

(a) $\mathrm{H} 1$

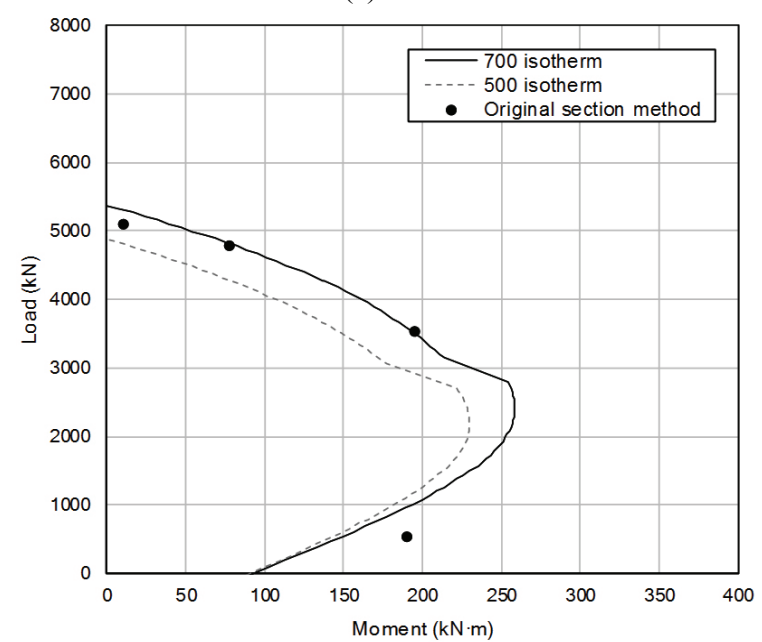

(c) $\mathrm{H} 3$

\section{Conclusions}

In this paper, analytical method of simplified section method was proposed and validated. From the validated method, P-M interaction diagrams of the fire-damaged RC columns having different heated areas were generated. The following conclusions can be drawn from the results.

(1) From axial loading test results, the residual strength of the columns decreased as the heated area increased.

(2) The reduced section method by removing part over 700 ${ }^{\circ} \mathrm{C}$ could capture structural behaviors of fire-damaged columns accurately, rather than the reduced section method with $500{ }^{\circ} \mathrm{C}$ isotherm.

(3) The predictions of the proposed P-M interaction diagram using the reduced section method were in good agreement with analytical results obtained from original section method.

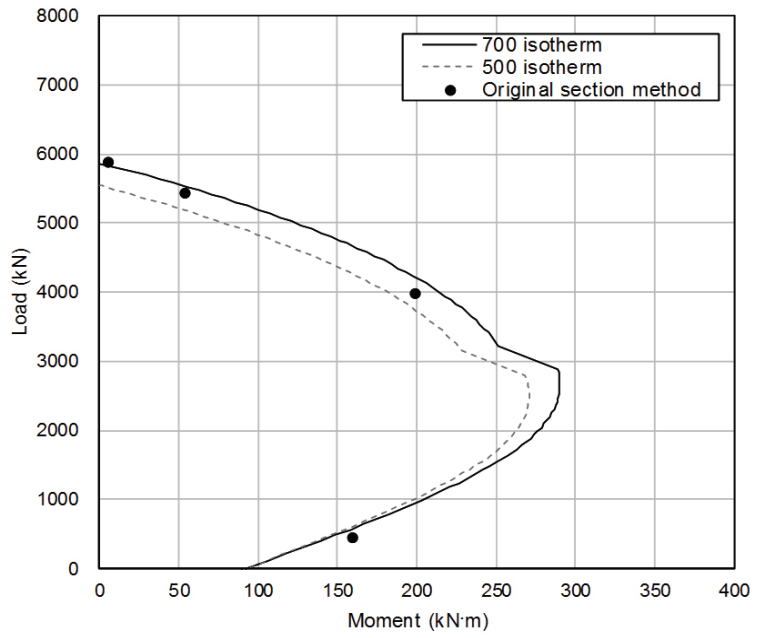

(b) $\mathrm{H} 2$

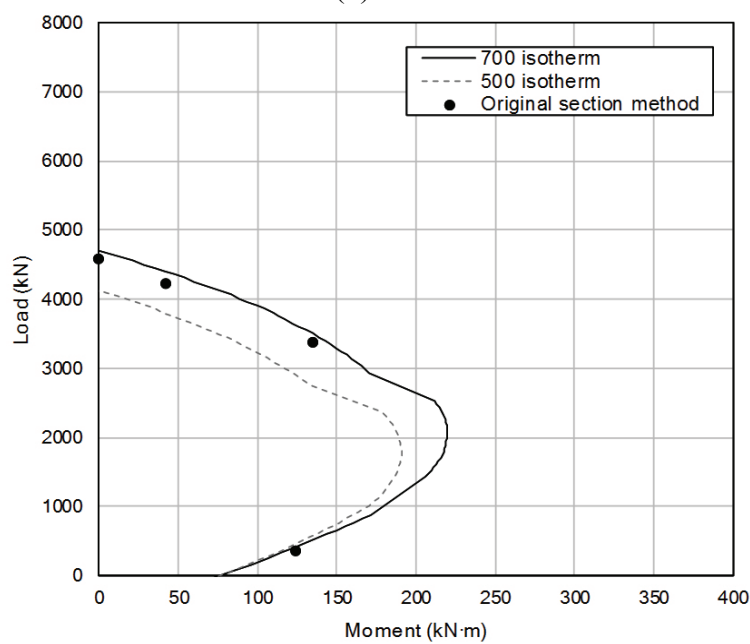

(d) $\mathrm{H} 4$

Fig. 6. P-M Interaction Diagrams of Fire-damaged RC Columns 
(4) The proposed P-M interaction diagram using the reduced section can be used to predict the strength and moment at various heated areas.

(5) The further studies are needed to investigate P-M interaction diagram including various cross-sectional size and fire exposure times exposed to fire for the fire-damaged $\mathrm{RC}$ columns.

\section{Acknowledgments}

This research was supported by a grant (20AUDPB100356-06) from Urban Architecture Research Program funded by Ministry of Land, Infrastructure and Transport of Korean government.

\section{References}

Buch, S.H., and Sharma, U.K. (2019). Fire resistance of eccentrically loaded reinforced concrete columns. Fire Technology, Vol. 55, No. 5, pp. 1517-1552.

Caldas, R.B., Sousa Jr, J.B.M., and Fakury, R.H. (2010). Interaction diagrams for reinforced concrete sections subjected to fire. Engineering Structures, Vol. 32, No. 9, pp. 2832-2838.

Dassault Systèmes. (2013) Abaqus analysis users' manual. ABAQUS Documentation.

El-Fitiany, S.F., and Youssef, M.A. (2014). Interaction diagrams for fire-exposed reinforced concrete sections. Engineering structures, Vol. 70, pp. 246- 259.
EN 1992-1-2. (2004). Eurocode 2: Design of concrete structures - Part 1-2: General rules - Structural fire design. European Committee for Standardization (CEN), Brussels, Belgium.

ISO 834. (1999). Fire resistance tests - Elements of building construction. International Organization for Standardization, Geneva, Switzerland.

Kim, H. (2008). A study on P-M interaction diagram of fire-damaged high strength concrete column. Master's thesis, Ewha Womans University, Korea.

Law, A., and Gillie, M. (2010). Interaction diagrams for ambient and heated concrete sections. Engineering Structures, Vol. 32, No. 6, pp. 1641-1649.

Mao, X., Kodur, V.K.R. (2011). Fire resistance of concrete encased steel columns under 3- and 4-side standard heating. Journal of Constructional Steel Research, Vol. 67, No. 3, pp. 270-280.

Ryu, E. (2020). Post-fire structural performance of high strength concrete walls and columns. Ph.D. dissertation, Ewha Womans University, Korea.

Tan, K.H., and Yao, Y. (2003). Fire resistance of four-face heated reinforced concrete columns. Journal of Structural Engineering, Vol. 129, No. 9, pp. 12201229.

\begin{tabular}{l|l} 
Received & March 26, 2020 \\
Revised & April 1, 2020 \\
Accepted & April 10, 2020
\end{tabular}

